\title{
Türkiye'de İç Göçlerin Toplumsal Yapıda Neden Olduğu Değişimler, Meydana Getirdiği Sorunlar ve Çözüm Önerileri
}

\section{Social Structural Changes, Related Problems and Proposed Solutions Caused By Internal Migrations in Turkey}

\author{
Hakan BOSTAN ${ }^{1}$ \\ ${ }^{1}$ Jandarma Genel Komutanlığı, Yenimahalle, Ankara, Türkiye
}

\section{öz}

Göç, en kısa tanımıyla çoğu canlının ve insanların bir yerden başka bir yere değişik sebepler yüzünden hareket etmesi/yer değiştirmesidir. Göç, bir ülke sınırları içerisinde gerçekleşiyorsa iç göç, ülke sınırını aşıyorsa dış göç (uluslararası göç) olarak isimlendirilir. Göçe; sosyal, ekonomik, askeri, kültürel, etnik sebepler neden olmaktadır. Türkiye'de iç göçler, İkinci Dünya Savaşı́ndan sonra özellikle sanayileşme faaliyetleri ve tarımda modernleşmenin etkisiyle başlamıştır. İç göçler ilk başlarda köyden kente doğru olurken daha sonraları küçük ve orta ölçekli şehirlerden büyük şehirlere olacak şekilde devam etmiştir. 1990'lı yıllarda kentten köye olmak üzere yeni bir göç şekli ortaya çıkmıştır.

İç göçler; hem göç veren, hem de göç alan yerleşim yerlerinde toplumsal değişimlere neden olmuştur. Bu değişimler ile birlikte özellikle kentlerde bir takım sorunlar ortaya çıkmıştır. Bu sorunlar ise halen yaşanmaya devam etmektedir.

Bu çalışmada; Türkiye'de iç göçler, iç göçlerin toplumsal yapıda neden olduğu değişimler, iç göçlerin meydana getirdiği sorunlar ve çözüm önerileri incelenmiş, yeni bir bakış açısı ile sonuca ulaşılmıştır.

Anahtar kelimeler: Göç, İ̧̧ Göç, Toplumsal Değişim

\section{ABSTRACT}

The simplest definition of migration is living things and people moving or relocating from one place to another. If migration takes place within the borders of a country, then it is called internal migration; if it crosses a country's border, it is called external or international migration. Migration can occur owing to social, economic, political, cultural, and ethnic reasons. Internal migration began with modernization in agriculture and industrialization activities after the Second World War in Turkey. Migration first occured from village to city, then from small- and medium-sized cities to large cities. In the 1990s, the shape of a new migration emerged: from cities to villages. Internal migration has caused social changes in both city and village settlements. Along with these changes, a number of problems emerged, especially in those of cities, and these problems exist till date.

This study examined internal migration in Turkey and the causes of change in social structure, the resulting problems and the recommended solutions, and a novel perspective regarding migration was developed.

Keywords: Migration, Internal Migration, Social Change 


\section{EXTENDED ABSTRACT}

The simplest definition of migration is living things and people moving or relocating from one place to another. If migration occurs within a country's border, then it is called internal migration; if it crosses a country's border, then it is called external or international migration. Migration can be caused by social, economic, political, cultural, and ethnic reasons. The causes of migration can be clarified through theories related to migration. A closer examination of theories related to migration reveal that a single theory cannot explain all aspects of migration. Therefore, it is necessary to adopt a comprehensive approach toward all theories related to migration to gain a holistic picture of the causes of migration.

The purpose of this study is to examine the recommended solutions from a social science point of view and arrive at a novel perspective by considering the changes and problems caused by internal migrations in Turkey in terms of its social structure. To achieve this purpose, data from sociologists, social anthropologists, and other researchers from this field of study have been used. This study has not considered surveys and previous studies (especially field studies) because this research subject required an intensive literature search.

To better understand the differences in the changes that internal migrations has caused in Turkey's social structure, they were chronologically classified into periods ranging from 1923 to 1950, 1950 to 1960, 1960 to 1980, and 1980 to 2000 and after. Turkish internal migrations began especially after the emergence of agricultural modernization and industrialization that occured after the Second World War.After the Second World War, the Turkish population moved out of villages rapidly; however, as the process of industrialization was slow when compared to that of the speed in migration, those who migrated from the village to city could not be included in the business processes in that of the same speed; further, there has been an intense social transformation process related to that of the problem of urbanization in Turkey.

At first, internal migrations occured from village to city, then it continued from small and medium sized cities to large cities. Since the 1990s, internal migrations have begun to transform villages into cities. This transformation was especially consequence of the spread of Turkish social security systems. From 2000, with the transition from traditional to information society, a large proportion of the population in particular, were urbanized. People's mobility has accelerated; consequently, people have started to move more frequently. People cannot be bound to a certain place anymore and they are constanty moving all through their lives. Internal migrations continue in Turkey till date. Nowadays, internal migrations have become unchecked and voluntary.

Internal migrations have caused social changes both in the rural and urban cultures in both city and village settlements, respectively and these contonue till date. The known rural and city cultures have transformed over time and this has led to the emergence of new syntheses. The changes in social structure caused by internal migrations have been examined through examples given by researches conducted by sociologists, social anthropologists. As a result of these changes, some problems emerged both in the past and continue to emerge in the present as well.

In the future, the growth in the world population will be concentrated in developing countries. Urbanization caused by the increase in urban population in these countries will lead to air, water, and noise pollution as well as increase in crime rates. 92,3 \%of Turkey's population live in the provincial and district centers (in the cities). According to population projections; the Turkish population belonging to 65 years and above will also increase. It is envisaged that the population increase of Turkey will continue until 2050. The population projections also reveal that the problems experienced in Turkey, similar to that of the entire world, will continue in the future as well.

In this study, in sum, internal migration management as well as solution suggestions for problems, caused by internal migrations, have been explored. The study's results are as follows - the decrease in internal migration with the measures taken at the point of migrants' return, it has been understood that improvement in the income between regions or settlements and the proposed solutions by cities to reduce attractiveness and the repulsive effects of the villages thereof are not valid in the present day conditions. As per official records, when taking into account the $92.3 \%$ of Turkish population, living in provincial and district centers, a new point of view has been adopted; migrant adaptation to city life should be ensured. For this purpose, appropriate strategies should be determined, solutions for the related problems should be proposed in terms of the participation of the many actors and a holistic approach should be adopted. 


\section{GÍRIŞ}

Göç, insan hayatında her zaman yer almıştır. İnsan çeşitli sebepler nedeniyle göç etmiş ve hâlen de göç etmeye devam etmektedir. Göç, kişilerin uluslararası bir sınırı geçerek veya vatandaşı olduğu devlet içinde yer değiştirdiği nüfus hareketidir (Göç Terimleri Sözlüğü, 2009). Göçler ülke içerisinde cereyan ediyorsa iç göç, ülke sınırını aşıyorsa dış göç (uluslararası göç) olarak isimlendirilir.

Türkiye'nin kurulmasında ve ulus-devlet olarak şekillenmesinde "içe ve dişa doğru gerçekleşen büyüklü küçüklü ama sürekli göç dalgaları” önemli rol oynamıştır (Gürsoy, 1998, s. 61). Bu göçler özellikle Osmanlı İmparatorluğu'nun son döneminde yoğunlaşmıştır. Cumhuriyetin ilanıyla başlayan ve 1950 yıllarına kadar devam eden uluslararası göçler, Türk ulusunun inşasında ve türdeş (homojen) bir toplum yaratılmasında nasıl önemli rol oynadıysa, 1950'lerde tarımda makineleşme ve sanayileşmeyle başlayan iç göçler de, 1960'larla birlikte dış göçü hazırlayan etmenlerden birisini oluşturmuştur. İnsanlar önce köyden kente göç etmiş ve sonra özellikle kentlileşmenin olumsuz etkisi ve Avrupa'nın iş gücüne olan talebi ile birleşerek insanların dışarıya göç etmesine zemin hazırlamıştır (İçduygu ve Ünalan, 1998, s. 45; Yalçın, 2004, s. 119).

Karpat (2015, s. xxiv), “Türkiye'yi kökünden etkileyen ve siyasetini, kültürünü, değerlerini, yaşam şekillerini derinliğine değiştiren iç göçlerin-yani köyden şehre göçlerin-önemi halen gereğiyle algılanmamıştır." şeklinde haklı bir eleştiride bulunmuştur. $\mathrm{Bu}$ makalenin beklenen faydalarından biri de, iç göçlerin öneminin algılanmasına katkıda bulunmasıdır.

İç göçler; hem göç veren hem de göç alan yerleşim yerlerindeki toplumsal yapıyı etkilemektedir. Toplumsal yapıda meydana gelen değişimler zamanla bir takım sorunlara yol açmıştır. Özellikle kentlerde yaşanan bu sorunlar karşısında farklı çözüm önerileri gündeme getirilmiştir. Halen bu sorunların devam ediyor olması, soruna farklı bir açıdan bakılmasını gerektirmektedir.

\section{VERİ VE YÖNTEM}

Çalışmada yoğun olarak Türkiye İstatistik Kurumunun (TÜIK) verileriyle diğer istatistik çalışmalardan faydalanılmıştır. Özellikle iç göçün toplumsal yapıda neden olduğu değişimin belirlenmesinde yöntem olarak; sosyologlar, sosyal antropologlar ve diğer araştırmacıların yaptıkları alan araştırmaların sonuçlarının değerlendirilmesine gidilmiştir. Araştırmanın konusu; yoğun bir literatür taramasını gerektirdiği için; çalışmada anket (survey) ve benzeri çalışmalara (alan araştırması vb.) ihtiyaç duyulmamıştır. Son bölümde iç göçün neden olduğu sorunlar açıklanmış ve çözüm önerileri karşılaştırılmıştır.

\section{KAVRAMSAL CCERÇEVE: GÖÇ KAVRAMI}

Göç, sadece insanların yaşadığ 1 bir olay değildir. Göç, canlıların büyük bir kısmı için geçerli olan ve yaşamlarını devam ettirebilmeleri için önemli bir koşul olan yer değiştirme eylemidir (Yalçın, 2004, s. 1). Canlılar göç ederek hayatta kalmışlardır. İnsanoğlunun var olmaya başlamasıyla birlikte göç olgusu da ortaya çıkmaya başlamıştır. O zamanki iklim şartları ve ekonomik sebepler buna sebep olmuştur. Avc1-toplayıcı grupların besin temin etmek zorunda kalmaları, insanoğlunun yiyecek bulma nedeniyle yaptıkları ilk göçleri oluşturur (Güvenç, 2002 s. 161). Buzulların erimesi gibi nedenler ile değişen doğal çevre şartları da bir diğer göç nedenini oluşturmuştur.

Göçün birçok değişik tanımı yapılabilir. Göç en genel tanımı ile insanların bir yerden başka bir yere değişik sebepler yüzünden hareket etmesidir. Erder (1986, s. 9), göçün oluşması için bir yer değiştirmenin "anlamlı bir uzaklık ve etki yaratacak kadar bir süre" içinde gerçekleşmesi gerektiğini belirtmiştir. Farklı disiplinlerin göçe bakış açıları şu şekildedir: "Farklı bilimsel disiplinler olarak ekonomi, sosyoloji, demografi, coğrafya, tarih, psikoloji, uluslararası ilişkiler, siyaset bilimi ve diğer bazı ilgili disiplinler göçle ilgili konulara farklı bakış açılarıyla değinirler" (İçduygu ve Ünalan, 1998, s.39).

Göçleri Petersen (1996) dört değiş̧ik şekilde tasnif etmiştir: İlkel göç, zorlama ile yapılan göçler, serbest göç, kitlesel göç (Aktaran Yalçın, 2004, s. 14-16). Akkayan (1979) ise göçleri iç göç bağlamında; güdümlü, mevsimlik, daimi, kademeli ve kademesiz olarak beş gruba ayırmıştır. Aslında göçü belli ölçülere göre sınıflandırmak gerekmektedir. Bu ölçülere göre yapılan sinıflamalar Tablo 1'de belirtilmiştir.

Tablo 1: Göç Tasnifleri (Yalçın, 2004, s. 17-20). Table 1: Migration Classifications (Yalçın, 2004, s. 17-20).

\begin{tabular}{lll}
\hline İrade Esasına Göre Göçler & Gönüllü Göçler & Zorunlu Göçler \\
\hline $\begin{array}{l}\text { Göçün Yoğunluğu Esasına } \\
\text { Göre Göçler }\end{array}$ & Kitlesel Göçler & Bireysel Göçler \\
\hline $\begin{array}{l}\text { Ülke Sınırları Esasına Göre } \\
\text { Göçler }\end{array}$ & İç Göçler & Dış Göçler \\
\hline $\begin{array}{l}\text { Yerleşim Sürelerine Göre } \\
\text { Göçler }\end{array}$ & Geçici Göçler & $\begin{array}{l}\text { Sürekli Yerleşmek Amacıyla } \\
\text { Yapılan Göler }\end{array}$ \\
\hline
\end{tabular}


Literatürde bazen de, göç tanımları yapmak yerine göç tipleri üzerinde isimlendirmeler yapılmaktadır. İçduygu ve Ünalan (1998, s. 45)'ın, tespit ettiği sekiz farklı göç türü şunlardır: İl merkezinden il merkezine, ilçe merkezinden il merkezine, il merkezinden ilçe merkezine, ilçe merkezinden ilçe merkezine, köyden ilçe merkezine, il merkezinden köye, ilçe merkezinden köye, köyden köye göç.

Göç türleri ile birlikte göç kararı ve göçün neden yapıldığı konusu da önemlidir. Özellikle araştırmacılar "göç kararı ve nasıl alındığı" noktasında yeterli çalışmalar yapmamışlardır. Bu eksende "Zincirleme göçler (chain migration)" ile "Aşamalı göçler (step migration)" önem kazanmıştır. Özellikle bu konuda Devlet İstatistik Enstitüsü'nün verilerinin yetersizliği de neden olmuştur (Özcan, 1998, s. 83-34). Aşamalı göçler bireylerin önce en yakın yerlere daha sonra da başlıca çekim merkezlerine yapılan göçlerdir. Zincirleme göç daha önce göç etmiş olanların aileleri veya yakın çevrelerinden (akrabaları, komşuları gibi) kimselerin enformel ve birincil ilişkiler yoluyla yapılan göçlerdir. İlk göçler genellikle geçici olarak yapılırken, bunu takip eden göçler olan zincirleme göçler ise kalıcı ve kitle göçü şeklinde olmaktadır (Erder, 1986, s. 18-19).

Göçler farklı disiplinler tarafından - ekonomi, demografi, sosyoloji, sosyal antropoloji, tarih, coğrafya vb. - ele alınmaktadır. Sertkaya-Doğan (2015, s. 18) göçün; sosyal, kültürel, ekonomik ve siyasi doğası yani çok yönlü doğası gereği; antropologlar, sosyologlar, şehir plancıları, idareciler ve benzeri çok çeşitli profesyonel geçmişi olan insanlar tarafindan incelenme konusu olduğunu belirtmiştir. Özellikle sosyal bilimcilerin yaptıkları bu çalışmaları bir arada değerlendirmeleri ve paylaşmaları önemlidir. Son yüzyılda bu çalışmalar yoğunlaşmıştır: "Göç sonucu yeni bir topluma giren nüfus kümelerinin o toplumla bütünleşmesi, kültürel farklılıkların sürdürülmesi ya da zaman içinde önemsizleşmesi, sosyal bilimler alanında çok geniş yelpazeli inter-disipliner bir yaklaşımla ele alınmaktadır" (Abadan-Unat, 2002, s. 25).

Karpat (2015, s. xxiii), göçlerin, toplumların kültüründe yarattığı etki ile yeni kültürler yaratmaktaki etkisini şöyle açıklamıştır: "Gerçekten toplumların kültürel değişim süreçlerinde, hatta çeşitli kültürlerin karışımından yeni kültürler yaratan ana güçlerden birisi göçtür". Göçlerin neden olduğu kültürel değişim etkisi, sosyal bilimciler tarafindan incelenmiştir. Antropoloji göçlerle ilgilenen bir bilim dalıdır. Antropologlar özellikle göçün ne zaman, niçin olduğuyla ve kimlerin göç ettiğiyle ilgilenmektedirler. Antropoloji aynı zamanda bir çevreden ayrılmanın ve diğer bir çevreye girmenin neden olduğu sosyal ve kültürel değişimler ile göçmen olma deneyiminin anlamıyla da ilgilenmektedir (Brettell ve Hollifield, 2000, s. 4).

Antropolojinin kültür üzerinde odaklaşması kültürel değişim ve uyum (adaptasyon) konularındaki göç çalışmalarının önemi üzerinedir. Brettell makalesinde; özellikle antropolojinin, toplumsal cinsiyet ve göç arasındaki ilişkiyi göz önüne alan adaptasyon süreci ve göç sosyal organizasyonların tartışmaları ile kimlik ve etnik kimlik teorileri ve göç teorileri arasındaki ilişkiyi analiz etmektedir (Brettell, 2000, s. 98).

Göçe; sosyal, ekonomik, askeri, kültürel, etnik gibi sebepler neden olmaktadır. Göçe neden olan faktörler göç teorileri/ kuramlar ile açıklık getirilmiştir. Göçle ilişkili teoriler/kuramlar; E.G.Ravenstein'in Göç Kanunları (1885-1889), Kesişen Fırsatlar Teorileri, İtme-Çekme Teorisi (Lee, 1966), Merkez-Çevre (Dünya Sistemleri) Teorisi (Bağımlılık Okulu düşünürleri tarafından geliştirilen), Parekh'in Göç Teori Sınıflandırmaları (Liberal, Toplumcu, Etnik ya da Milliyetçi görüş), Marxist Teori, Göçmen İlişkiler Ağı (Network) Teorisi, Asimilasyondan Çokkültürlük, Etnisite Teorileri, Ekonomik Temelli Göç Kuramları (Neo-Klasik, Yeni Ekonomi ve İkiye Bölünmüş Emek Piyasası Kuramı), Sosyo-kültürel göç kuramları olarak modernleşme okulu düşünürleri tarafindan geliştirilen Denge Kuramı ile Göç Sistemleri Kuramı, Kurumsal Kuram, Birikimli (Kümülatif) Nedensellik Kuramlarıdır (Abadan-Unat, 2002, s. 20-21; Adıgüzel, 2016, s. 27-33; Yalçın, 2004, s. 22-96). Klasik ve neo-klasikler olarak ikiye ayrılan iktisatçllar ise; göçe faydamaliyet yaklaşımı ile açıklama getirmişlerdir. Klasikçi yaklaşımın öncüsü Thedore William Schultz olup, bireylerin, daha iyi işler bulabilecekleri kentlere göç edeceklerini, Neoklasik yaklaşımcı Michael P. Todaro da bölgeler arası sosyoekonomik eşitsizliklerin göçe neden olduğu üzerinde durmuştur (Çelik, 1999; Çelik, 2007, Todaro 1996). Göç araştırmalarında en çok kullanılan itme ve çekme teorisinde; Everett Lee (1969), "Bir Göç Teorisi”" (A Theory of Migration) adlı makalesinde; insanların (göçmenlerin) yaşadıkları yerleri terk etmelerine neden olan faktörlere itici, gidilecek yeri cazip hale getiren faktörlere de çekici faktörler olarak tanımlamıştır (Yalçın, 2004, s. 30).

İç göçleri açıklamada en önemli teorilerden birisi ve göçle ilgili ilk çalışma olan Alman-İngiliz coğrafyacı ve harita uzmanı olan Georg Ravenstein'in yedi göç kanunu ise:

1. Göç ve Mesafe; "göçmenlerin büyük çoğunluğu kısa mesafeli bir yere göç ederler.”, 2. Göç ve Basamakları; "kentlerde meydana gelen ekonomik gelişme, yakın yerlerden göçmenleri hızla bu kentlere getirir.”, 
3. Yayılma ve Emme Süreci,

4. Göç Zincirleri; "her göç dalgası karşı dalga yaratır.",

5. Doğrudan Göç; “uzak mesafeye göç edenler, daha çok büyük endüstri merkezlerini tercih ederler.”,

6. Kır Kent Yerleşimleri Fark1; "kentlerde yaşayanlar, kırsalda yaşayanlardan daha az göç ederler.”,

7. Kadın Erkek Fark1; "kadınlar erkeklere göre daha fazla göç eğilimi içindedirler.”.

Türkiye'de yaşanan iç göçlerde belirtilen hususların bir kısmı, Ravenstein'in göç kanunlarına uymamaktadır. Farklı zaman ve yerde oluşturulan bu kanunların bir kısmının Türkiye koşullarına birebir uymaması normaldir (Abadan-Unat, 2002, s. 4-5; Yalçın, 2004, s. 22-27:). Tek bir teori göçün her yönünü açıklamamaktadır. $\mathrm{Bu}$ nedenle teorilere bir bütün olarak yaklaşmak gerekmektedir.

Bundan sonraki bölümlerde; Türkiye'de iç göç ve iç göçlerin toplumsal yapıda neden olduğu değişimler; sosyologlar, sosyal antropologlar ve diğer araştırmacıların bakış açısıyla incelenecektir.

\section{TÜRKIYY'DE İÇ GÖÇ}

İç göçler, bir ülke sınırları içinde yapılan göçleri kapsamaktadır. En genel tanımı belli bir süre kalmak amacıyla, ülke sınırı içinde bir yerden başka bir yere yapılan göçe, iç göç denilmektedir. Bu konuda Tekeli'nin tanımı zaman, yer ve irade olarak belirtilmiş bir tanım olarak önemlidir: "İçgöç, belli bir zaman dilimi içinde belli bir yerleşme alanında yaşayanların, kendi iradeleriyle yaşam yerlerinin söz konusu yerleşme alanı dışına taşıyanların miktarı olarak tanımlanmaktadır" (Tekeli, 1998, s. 9).

Göç çalışmalarında, genellikle temel istatistik sayımların yer aldığı süreler dikkate alınmıştır. Genellikle; 1, 5, 10 gibi yıllar ile sayım esnasında geçen süreler dikkate alınmıştır (Özcan, 1998, s. 80). Bununla birlikte daha kısa süreleri dikkate alan araştırmacılar da olmuştur. Genel bakış, göç için geçerli zaman anlamlı bir etki yaratan bir süreçtir.

Türkiye'de, özellikle İkinci Dünya Savaşı'ndan sonra sanayileşme faaliyetlerinin başlamasıyla birlikte iç göçlerde başlamıştır. Başta İstanbul ve yakın çevresi olmak üzere sanayide pilot bölgeler tespit edilmiştir. Bu bölgelere; sanayi faaliyetlerin başlaması sonrasında, kırsal kesimden (köylerden) göç hareketi başlamıştır. Sonrasında ise; tarımda modernleşme ve hızlı nüfus artışı iç göçlere ivme kazandıran yeni etmenleri oluşturmuştur. Aslında köylerden kente yaşanan ilk göçlerin sebebi köylerde yaşanan ekonomik yoksunluktur. Göçler ilk başlarda köyden kente doğru olurken, daha sonraları da küçük ile orta ölçekli kentlerden büyük kentlere doğru olarak devam etmiştir.

Tekeli ve Erder (1978) tarımsal modernleşmeyi üç bölümde incelemiştir: 1948-1956 Dönemi: Modernleşmenin başladığı ilk dönemdir. Marshall programı başlamış ve ülkedeki traktör sayısı 1800'den 44000'e çımıştır. Bu dönemde ekim alanları 13.768 bin dekardan 19.173 bin dekara çıkmış ve bunun sonucunda tarımsal üretim çoğalmıştır. 1957-1963 Dönemi: Dış ödemeler konusunda sıkıntıların yaşanması sonucu traktör ithalatına son verilmiş ve traktör sayısı 44.000 'de sabit kalmıştır. 1964-1970 Dönemi: Ülke içinde montaj olarak traktör üretimine başlamış, 1970 'de traktör sayıs1 105.865 'e, 2001'de \%895 artarak 948.416'ya yükselmiştir (Doğan, 2005, s. 68-70; Yalçın, 2004, s. 111). Makineleşme köylerde iş gücü fazlalığını, kentlerde ise iş gücü ihtiyacını ortaya çıkarmıştır. Bu üç dönem, tarımda modernleşmenin kırda yarattığı değişim sürecini göstermektedir. $\mathrm{Bu}$ süreç iç göçü yaratan bir süreç olmuştur.

Yalçı, Görmez (1997)'in iç göçün nedenleri olarak; hızlı nüfus artışı, traktörün girişi, radyonun yaygınlaşması, ulaşım araçlarının gelişmesi, 1950'lerdeki karayolu yapımının hızlanması ve sanayileşme olarak belirttiğini söylerken, radyonun yaygınlaşması ve ulaşım araçlarındaki gelişmelerin göçün nedeni olarak değil göçe etki eden unsurlar olarak görmek gerektiğini belirtmiş̧ir (Yalçın, 2004, s. 112).

Köyden kente olan iç göçlerin nedenlerinden biri de köyün itici ve kentin çekici özellikleri olmuştur. İtici faktörler köyde artan hızlı nüfus baskısı, yetersiz ve kötü dağılmış toprak, düşük verimlilik, doğal afetler, kan davaları, toprağın miras yoluyla paylaşılması ve bazı kişilerde yoğunlaşması, tarımda makineleşmeyle ortaya çıkan işsizlik, terör ve güvenlik sorunları olmuşken, çekici faktörler ise köy-kent gelir farklılığı, daha iyi eğitim ve sağlık istemi, kentin çekiciliği, ulaşım ve iletişim olanakları, iş bulma ümidi, daha yüksek hayat standardı isteği ve kentlerdeki toplumsal ve kültürel olanaklardan yararlanma imkânları olmuştur (İçduygu, Sirkeci ve Aydıngün, 1998, s. 217).

Akşit, köyden kente olan göçlerin nedenlerini köyün itici ve kentin çekici faktörlerinden farklı olarak şöyle belirtir: "Köyden dışarı göçler, orta gelişmişlik düzeyinde yani köye modern teknolojinin girdiği, işlenebilecek toprağın sınırlarına varıldığı ve toprağın parçalanma tehlikesinin ve kentteki ilişkiler yoluyla daha iyi iş veya hizmet olanaklarının algılandığı noktaya varıldığı anda gerçekleşmektedir" (Akşit, 1998, s. 26). 
İtici sebepler daha çok köyün kendisinde barındırdığı olumsuz koşullardan kaynaklanmaktadır. Aslında bu itici ve çekici faktörlerin fiziksel coğrafi şartlara bağlı olması da önemli bir noktadır (Bergman, 1995, s. 158). Göçe neden olan bu itici ve çekici faktörler aslında sadece ilk koşuldur. Bunun yanında gidilecek yerin uzaklığı, göç etmeyi düşünen bireyin yaşı, medeni durumu, çocuk sahip olup-olmama durumu ve cinsiyeti göç kararı vermede önemli derecede rol oynamaktadır (Yalçın, 2004, s. 33). Belirtilen bu durumların yanında aslında birey göç kararı vermeden önce üç durumu değerlendirmesi gerekmektedir: Bireyin mevcut durumu, bireyin diğer yerdeki imkânları nasıl gördüğü, bireyin bir mekândan diğerine göç etmeden önce engellerin üstesinden gelebilme ihtimalleri (Engelbrektsson, 1978, s. 18).

Türkiye'de iç göçlerin toplumsal yapıda neden olduğu değişimlerdeki farklılıkların daha iyi anlaşılması açısından iç göçler; 1923-1950, 1950-1960, 1960-1980, 1980-2000 yılları arasındaki dönem ile 2000 yılı sonrası olarak tarihsel olarak sınıflandırılmıştır.

\section{1. 1923-1950 Yılları Kapsayan Dönem}

Başkent olmasıyla birlikte ilk iç göçler Ankara'ya doğru olmuştur. Göçmenler; daha çok kamu kurumlarında çalışmak üzere ve Ankara'nın başkent olması sebebiyle yeni iş istihdamlarının oluşması nedeniyle göçü tercih etmişlerdir.

Türkiye'de 1950 tarihinden öncesi iç göçler, mevsimlik göçlerin giderek yoğunlaştığı bir dönem olmuştur. $\mathrm{Bu}$ dönemde toprağı kıt olan ve toprak insan dengesinin sınırına ulaşılmış ve toprakların genişletilme imkânı olmayan köylerde toprak parçalanması ve topraktan kopma yani göçler başlamıştır (Akşit, 1999). 1929 ve 1950 yılları arasında iç ve dış göçlere kolaylık sağlanmıştır. Buna, Türkiye'nin ilk nüfus politikası olan ekonomik nedene dayanan hızlı nüfus artışının hedef alınması neden olmuştur (Doğan, 2013, s: 24). Bu dönemde daha çok köylerin modernizasyonu süreci rol oynamıştır. 1923 yllında Türkiye nüfusunun $\% 24,22$ 'ü kentlerde, $\% 76$ 's1 ise belde ve köylerde yaşamaktadır. 1950 'de kentlerde nüfusun oranı sadece 0.82 artış ile \%24,94'e çıkmıştır. Henüz köyden kente gerçekleşecek göç süreci başlamamıştır.

\section{2. 1950 ve 1960 Yılları Kapsayan Dönem}

1950'li yıllarda sanayileşme faaliyetlerin etkisi ve sonrasında tarımda modernleşmeyle iç göçler, "kırsal alandaki ekonomik ve toplumsal değişim” ile başlamış ve hızlanmıştır. 1950-1955 dönemi aynı zamanda Türkiye'de ilk sanayileşme faaliyetlerinin başladığı dönemdir. Bu dönemde geleneksel toprak sahipliği sisteminin değiştiği, topraksızlaşma veya toprağın belli kişilerde birikmesi ve ulaşım koşullarındaki gelişmeler sonucu kırsal kesimden kente doğru bir hareket başlamıştır. Bu süreç 19501960 yıllarında devam etmiştir. Buna hız kazandıran koşullar ise nüfus artı̧̧1, tarımda düşük üretkenlik, köylerde oluşan işsizlik ve eğitim nedeni ile kentlere olan yönelmedir (İçduygu ve Ünalan, 1998, s. 43).

1950 ve 1960 yıllarını kapsayan bu dönemde özellikle traktörün tarıma girmesi sonucu fazla insan gücüne olan gereksinim azalmıştır. Bundan en çok olumsuz etkilenenler ilk zamanlarda küçük çiftçiler ve "ortakçıları" olmuştur (Yalçın, 2004, s. 115). Bu değişim ile köyde toplumsal yapı değişmeye başlamış özellikle küçük çiftçiler artık işçi statüsüne geçmişlerdir.

Türkiye'de iç göç, batı da olduğu gibi sanayiye bağlı olarak gelişmemiştir. 1950'li yıllarda köyden kente olan yoğun göç yeterli endüstri olmaması nedeni ile kentleşmenin sanayileşme olmadan gerçekleşmesine ve "kent köylüleri ve yarı kentleşme" (Karpat, 2003, s. 45) kavramların oluşmasına yol açmıştır. Kentlerde araştırma yapan antropologlar aslında "kentteki köylüler" ile karşılaşmakta ve araştırmalarını kentle bütünleşememiş "kentleşen köylüler" ile yapmaktadırlar (Tezcan, 2008, s. 32, s. 179).

\section{3.1960 ve 1980 Yılları Kapsayan Dönem}

1960'larla 1980'ler arasında kente olan akımın, kentlerin nüfusunu ve sayısını artırması "kentleşme" sonucunu doğurmuştur. Sanayileşmeye başlayan Türkiye gelen göçmenleri barındırabilecek konut ve onlar için yeterli istihdam sağlayamamış "gecekondulaşma" ile "kayıt-dışı ikincil ekonomik sektörün" büyümesine neden olmuştur (İçduygu, Erder ve Gençkaya, 2004, s. 180). Bu göçlerle birlikte, kentlerde çarpık yerleşmeler ortaya çıkmış ve istihdam sorunu yaşanmaya başlanmıştır (Doğan, 2011, s. 97). Kentlerin alt gelir gruplarının yaşadığı gecekondu bölgelerinde, işsizliğin de etkisiyle hırsızlık, cebir, şiddet vb. suçlar daha çok görülmeye başlanmıştır (Temurçin ve Sargın, 2011).

$\mathrm{Bu}$ göçe bu evrede neden olan etmenler ise; özellikle ilk göç ile ortaya çıkan göçmen ağlarının yarattığı olumsuz etki,kır-kent gelir dağılımının artması, kentlerin ekonomik ve toplumsal çekiciliğinin yükselmesi ve ulaşım ve iletişim alanındaki gelişmelerdir. Bu metropol illerin (Ankara, İstanbul, İzmir gibi) oluştuğu dönem olmuştur. 1960-1970 yıllarında göçlerin önemli 
kısmı köyden kente olurken, 1970'lerin sonlarında da kentten kente doğru oluşmuştur (İçduygu ve Ünalan, 1998, s. 43). Kentten kente olan göçler; 1965-1970 döneminde toplam göçlerin \%47'si iken, 1980-1985 döneminde \%56,18 olmuştur (Özcan, 1998, s. 87). 1965 ile 1985 döneminde kentten köye olan göç ise (bu oran yaklaşık 8.000.000 kişi), köyden kente olan göçün yarısı kadar olmuştur (Akşit, 1998, s. 25; Özcan, 1998, s. 87).

1960 ve 1980 yılları arasında Türkiye'de göçle yaşanan sağlıksız kentleşme sonucu ortaya çıkan bir oluşumu ise Tütengil şu şekilde belirtmiştir: "Sanayileşme ile atbaşı yürümeyen, sağlıksız, başka bir değişle "Demografik" nitelikleri ağır basan az gelişmiş kentleşmemiz kırsal bunalımın kente taşınmasının ötesinde bir oluşumu ortaya koymaktadır. $\mathrm{Bu}$ oluşum, “Köylülerin kentlileşmesidir” (Tütengil, 1985, s. 143-144).

Bu dönemde ayrıca köylerde yaşanan olumsuz hayat şartları ve kentlerdeki özellikle "Medya" sayesinde öğrenilen firsatlar ile çocuklara daha iyi bir gelecek hazırlama isteği göçü hızlandıran diğer sebeplerdir. Bunda en önemli etki psikolojik tesiri olan "Medya" ve göçmen ağlarıdır (Yalçın, 2004, s. 116).

\section{4. 1980 ve 2000 Yılları Kapsayan Dönem}

1980'lerden itibaren yoğunlaşan kentten kente göç olgusu, ulusal kalkınmacı politikaların yerine, liberal düşüncenin egemen olmaya başlaması, özelleştirmenin başlaması ile ekonomide liberalizme geçiş ve ekonominin uluslararası boyut kazanması sonucu gerçekleşmiştir (Peker, 1999, s. 295). Bu kapsamda özellikle 1985-1990 döneminde kentten kente göç toplam göçlerin \%62,18'ini oluşturmuştur (Tablo 2). Bu süreçte özellikle İstanbul, İzmir, İzmit, Ankara vb. büyük sanayi ve metropol iller çekici güç olmuşlardır.
1950-1985 arası köylerden kentlere göçün hızlandığ1 dönemdir. 1945-1950 yıllarında köyden kente olan iç göç 214.000 iken, bu sayı 1950-1955 arasında \%422 artarak 904.000 olmuştur. Bu artış; 1950 yılı köy nüfus oranının \%75'den, 1955 yılında \%71,21'e gerilemesine sebep olmuştur. 1950-1955 yılları birinci grup köylerden göçlerin hızlandığı dönem olmuştur. $\mathrm{Bu}$ köyler özellikle İstanbul, Ankara ve İzmir'den oluşmuştur. 19651970 yıllarında özellikle ikinci gruptakiler toprağı bol olan köylerden göçler başlamıştır. Bu köyler Orta Anadolu ve Karadeniz Bölgelerindeki köylerdir. 1980-1985 yıllarında ki iç göçler Doğu ve Güneydoğu Anadolu köylerinin modern teknoloji ile tanışmaları veya işlenebilecek toprakların sınırlarına gelinmesi sonucu oluşmuştur (Akşit, 1998, s. 25-26).

1945-1990 arasında kentsel büyüme; kırdan (köyden) kente olan göçten (\%52) kaynaklanırken, doğal nüfus artışı (\%30), kentlerin yeniden sınıflandırılması (\%15) ve yurt dışına yapılan göçler (\%3) değişik oranlarda da etkili olmuştur (İçduygu vd., 1998, s. 208-209). Bunun yanında; ölüm oranlarındaki hızlı düşüş ve sabit kalan doğum oranları da bunda etkili olmuştur (Yalçın, 2004, s. 113). 1927 yılında Türkiye'de köy nüfus oranı \%75,78 iken, 2016 yılında bu oran \%7,70'a düşmüş, kent nüfus oranı \%24,22'ten \%92,3'e çıkmıştır. 2007 yılından itibaren Adrese Dayalı Nüfus Kayıt Sistemine (ADNKS) geçilmiş olup, 2007-2016 yılları nüfus kayıtları ADNKS esaslarına göre hesaplanmıştır. 2008 ve 2013 yıllarındaki farkın ana nedeni ise 5747 ve 6360 sayılı yasa uyarınca Büyükşehir Belediye Kanununda yapılan idari bölünüş değişiklikleridir. 2016'da köy nüfus oranı \% $\%, 70$ 'a düşmüş, kent nüfus oranı \%92,30'a çımış, aradaki bu fark yukarıda belirtilen kanun değişiklikleri nedeniyle oluşmuştur (Tablo 3). Aslında bu suni durum gerçeği tam olarak göstermemekte olup, gerçek köy nüfus oranının \%20'ler seviyesinde olduğu değerlendirilmektedir.

Tablo 2: Yerleşim Yerlerine Göre Göç Eden Nüfus (1975-2015) (TÜIK, 2016a).

Table 2: Migration Population by Location (1975-2015) (TÜiK, 2016a).

\begin{tabular}{|c|c|c|c|c|}
\hline Yerleşim yeri & $1975-80$ & $1980-85$ & $1985-90$ & $1995-2000$ \\
\hline \multirow{2}{*}{ Toplam } & 3.584 .421 & 3.819 .910 & 5.402 .690 & 6.692 .263 \\
\hline & $(\% 100)$ & $(\% 100)$ & $(\% 100)$ & $(\% 100)$ \\
\hline \multirow{2}{*}{ Şehirden şehire } & 1.752 .817 & 2.146 .110 & 3.359 .357 & 3.867 .979 \\
\hline & $(\% 48,90)$ & $(\% 56,18)$ & $(\% 62,18)$ & $(\% 57,80)$ \\
\hline \multirow{2}{*}{ Köyden şehire } & 610.067 & 860.438 & 969.871 & 1.168 .285 \\
\hline & $(\% 17,02)$ & $(\% 22,53)$ & $(\% 17,95)$ & $(\% 17,46)$ \\
\hline \multirow{2}{*}{ Şehirden köye } & 692.828 & 490.653 & 680.527 & 1.342 .518 \\
\hline & $(\% 19,33)$ & $(\% 12,84)$ & $(\% 12,60)$ & $(\% 20,06)$ \\
\hline \multirow{2}{*}{ Köyden köye } & 528.709 & 322.709 & 392.935 & 313.481 \\
\hline & $(\% 14,75)$ & $(\% 8,45)$ & $(\% 7,27)$ & $(\% 4,68)$ \\
\hline
\end{tabular}


Tablo 3: Türkiye'nin Şehir ve Köy Nüfusu (1927-2016) (TÜIK, 2016b,c).

Table 3: Turkey's Rural and Urban Populations (1927-2016) (TÜIK, 2016b,c).

\begin{tabular}{|c|c|c|c|c|c|}
\hline Sayım Yılı & Toplam Nüfus & Şehir Nüfusu & Oran & Köy Nüfusu & Oran \\
\hline 1927 & 13.648 .270 & 3.305 .879 & 24,22 & 10.342 .391 & 75,78 \\
\hline 1935 & 16.158 .018 & 3.802 .642 & 23,53 & 12.355 .376 & 76,47 \\
\hline 1940 & 17.820 .950 & 4.346.249 & 24,39 & 13.474 .701 & 75,61 \\
\hline 1945 & 18.790 .174 & 4.687 .102 & 24,94 & 14.103 .072 & 75,06 \\
\hline 1950 & 20.947 .188 & 5.244 .337 & 25,04 & 15.702 .851 & 75,00 \\
\hline 1955 & 24.064 .763 & 6.927 .343 & 28,79 & 17.137 .420 & 71,21 \\
\hline 1960 & 27.754 .820 & 8.859 .731 & 31,92 & 18.895 .089 & 68,08 \\
\hline 1965 & 31.391 .421 & 10.805 .817 & 34,42 & 20.585 .604 & 65,58 \\
\hline 1970 & 35.605 .176 & 13.691 .101 & 38,45 & 21.914.075 & 61,55 \\
\hline 1975 & 40.347 .719 & 16.869 .068 & 41,81 & 23.478 .651 & 58,19 \\
\hline 1980 & 44.736 .957 & 19.645 .007 & 43,91 & 25.091 .950 & 56,09 \\
\hline 1985 & 50.664 .458 & 26.865 .757 & 53,03 & 23.798.701 & 46,97 \\
\hline 1990 & 56.473 .035 & 33.326 .351 & 59,01 & 23.146 .684 & 40,99 \\
\hline 2000 & 67.803 .927 & 44.006 .274 & 64,90 & 23.797.653 & 35,10 \\
\hline 2007 & 70.586 .256 & 49.747 .859 & 70,5 & 20.838 .397 & 29,5 \\
\hline 2008 & 71.517 .100 & 53.611 .723 & 75,0 & 17.905 .377 & 25,0 \\
\hline 2009 & 72.561 .312 & 54.807 .219 & 75,5 & 17.754 .093 & 24,5 \\
\hline 2010 & 73.722 .988 & 56.222 .356 & 76,3 & 17.500 .632 & 23,7 \\
\hline 2011 & 74.724.269 & 57.385 .706 & 76,8 & 17.338 .563 & 23,2 \\
\hline 2012 & 75.627 .384 & 58.448 .431 & 77,3 & 17.178 .953 & 22,7 \\
\hline 2013 & 76.667 .864 & 70.034 .413 & 91,3 & 6.633 .451 & 8,7 \\
\hline 2014 & 77.695 .904 & 71.286 .182 & 91,8 & 6.409 .722 & 8,2 \\
\hline 2015 & 78.741 .053 & 72.523 .134 & 92,1 & 6.217 .919 & 7,9 \\
\hline 2016 & 79.814 .871 & 73.671 .748 & 92,3 & 6.143 .123 & 7,7 \\
\hline
\end{tabular}

2000 yılı genel nüfus sayımına göre yapılan değerlendirmelerde iller arası göç etme nedenleri olarak ilk beş sırayı; hanedeki fertlerden birine bağlı $(\% 25,67)$, iş arama amaciyla $(\% 20,05)$, tayin-atama ile $(\% 13,42)$, eğitim amacı ile $(\% 11,56)$, evlilik amaciyla $(\% 7,43)$ ve deprem nedeniyle yapılan $(\% 3,6)$ göçler almaktadır (TUİK, 2005, s. 13).

1980 ve 1990'l1 yıllar serbest piyasa ekonomisinin, özelleşmenin ve küreselleşmenin etkilerinin bariz olarak hissedildiği dönem olmuştur. İletişim ve ulaşım koşullarındaki oluşan süreklilik, bireysel yaşamın toplumsal yaşam karşısında öneminin artması ve sivil toplumun siyasal toplum karşısında öneminin artması bu dönemin en önemli sonuçlarıdır. $\mathrm{Bu}$ dönemde siyasal nedenlerin katkısı (Doğu Anadolu ve Güney Doğu Anadolu bölgesindeki terör olayları ve kan davaları gibi) ile iç göçler artmıştır. $\mathrm{Bu}$ dönemde insanların toplumsal hareketliliği artmış ve halen de artmaya devam etmektedir (Adigüzel, 2016, s. 43; İçduygu ve Ünalan, 1998, s. 44). 1980'lerde liberal ekonominin uygulanması hizmet ve sanayi sektöründe önemli artışlara neden olurken, tarım sektöründe ise düşüşe neden olmuştur. $\mathrm{Bu}$ da köyden kente olan göçü hızlandırmıştır (İçduygu vd., 1998, s. 208-209).

Başbakanlık Devlet İstatistik Enstitüsü tarafından yapılan 2000 yılı göç istatistiklerinde, 1995-2000 döneminde yerleşim yerleri (il merkezi, ilçe merkezi, bucak, köy) arasında göç eden nüfus 6.692.263, iller arasında göç eden nüfus 4.788.193'tür. 1995-2000 yılları arasında her yüz kişiden 11'i yerleşim yerleri arasında, (8'i de iller arasında) göç etmiştir. Son 25 yılda göç eden nüfus büyüklüğü iki kat artmıştır (TUİK, 2005, s. 10).

Çelik (2007), Türkiye'deki iç göçlerin yönünün "doğu-batı" şeklinde olduğunu, gelir ve göç ilişkisinin; regresyon yöntemiyle yapılan analizinde bölgenin net göç almasında gelirin payının \%72 olduğu sonucuna varmıştır. Ayrıca Marmara, Ege ve Akdeniz bölgelerinin net göç aldığı sonucuna ulaşmıştır. $\mathrm{Bu}$ 
bölgelerin; 1985-1990 yılları arasında net göç oranlarında önemli bir artışa karşın, 2000 y1lında önemli bir azalma görüldügüu, net göç veren İç Anadolu Bölgesi'nin ise 2000 yılından itibaren net göç aldığını, göç veren bölgelerin gelir düzeyi düşük Karadeniz, Doğu ve Güneydoğu Anadolu olduğunu belirtmiştir. 2000 y1lı nüfus sayımı sonuçlarına göre, iller arası göç eden nüfusun yaklaşık beşte biri (\%22,4'ü) İstanbul'a göç etmiştir.

1995-2000 yıllarında Türkiye'de 23 il verdiğinden daha fazla göç alırken, 58 il de aldığından daha fazla göç vermiştir. Yirmi beş yıllık dönemde İstanbul, Ankara ve İzmir illeri, net göç eden nüfus büyüklüğü itibarıyla ilk sıralarda yer almışlardır. Sıraları değiş̧mekle birlikte Bursa, Kocaeli, Ankara, Mersin illeri de net göç eden ilk 10 il arasında yer almışlardır. 1995-2000 yıllarında önceki yıllarda yoğun bir göçle karşılaşmayan Tekirdağ, Muğla ve Antalya gibi sahil kentleri 1980'lerde başlayan turizm faaliyetlerinin sonucu iş istihdamın artmasına bağlı olarak en fazla göç alan iller ve yeni çekim merkezleri olmuştur. İstanbul nüfus ve istihdam bakımından artık doygunluğa ulaştı̆ı için sanayi faaliyetleri Tekirdağ'a (özellikle Çorlu-Çerkezköy'e) kaymıştır. Bu nedenle Tekirdağ son dönemde çok fazla göç almaktadır. Aldığı göçten daha fazla göç veren iller arasında, 1975-1990 döneminde Kars ili ilk sirada olmak üzere, Sivas, Tunceli ve Erzurum illeri, 1995-2000 döneminde de Ardahan, Bartın ve Sinop illeri yer almaktadır. 1975-1990 yılları arasında en fazla göç alan iller arasında olan Kocaeli, 1999 depremi sonucunda 1995-2000 yıllarında net göç hızı sıfıra yakın gerçekleşti. 1995-2000 yılları arasında göç sürecinde en önemli değiş̧im kentten (şehirden) köye doğru olmuştur. Bu değişim yaklaşık iki kat olmuştur. Bu oran bütün yapılan göçlerin \%20 ,06’sını içermektedir. Göç eden nüfusun yoğunluğu olarak en fazla göç ise şehirden şehre (kentten kente) olan göçtür. Bu oran 1990-1995 yıllarında \%62,18 iken, $1995-2000$ yıllarında $\% 57,80$ olmuştur (TÜIK, 2005, s. 10-12).

İç göçlerde göçmenlerin kültürel özellikleri dikkate alındığında; 1995-2000 döneminde göç etmiş kişiler arasında okuma yazma bilenlerin ve özellikle ilkokuldan mezun olanların payının çok yüksek olduğu gözükmektedir. Göç eden erkeklerin kadınlara nazaran eğitim seviyesi daha yüksektir. Göçler 20-24 yaş grubunda $(\% 20,58)$ yoğunlaşmaktadır. Erkekler $(\% 54,4)$, kadınlardan \%20 daha fazla göç etmektedir. Genç (5-14 yaş) ve orta yaş (15-64 yaş) grubundaki erkekler kadınlara nazaran, ileri yaşlarda (65 yaş ve üzeri) ise kadınlar erkeklere nazaran daha fazla göç etmektedir. Hiç evlenmemiş erkekler $(\% 50,89)$ ve evli kadınlar $(\% 62,89)$ daha fazla göç etmektedir. Erkeklerin çoğunluğu iş arama/bulma ve tayin/atama nedeniyle göç etmiş iken, kadınların çoğunluğu evlilik ve eğitim nedeniyle göç etmişlerdir. Göç eden erkekler (\%75,6), göç eden kadınlara (\%36) nazaran daha fazla istihdam imkânı bulmuştur. Göç eden nüfusun çoğunluğu hizmet sektöründe çalışmaktadır. Göç eden nüfusun büyük çoğunluğu ücretli ve maaşlı işlerde çalışmaktadır. 2000 yılında nüfusun \%72,2'si doğduğu ilde, \%27,8'i ise doğduğu ilin dışında bir ilde ikamet etmektedir (2015 yılı ADNKS göre ise nüfusun \%64,9’u doğduğu ilde ikamet etmektedir). En fazla göç alan illerde ikamet edenler içinde, başka illerde doğanların payı oldukça yüksektir. İkamet ettiği ilin toplam nüfusu içinde, başka il doğumluların en fazla olduğu illerin başında Yalova $(\% 63,4)$, doğduğu ilden başka ilde ikamet edenlerin en fazla olduğu illerin başında Tunceli ili $(\% 69,9)$ gelmektedir. Doğduğu ilden başka ilde ikamet edenlerin en az olduğu illerin başında Antalya $(\% 8,5)$ gelmektedir (TÜİK, 2005, s. 13-20).

\section{5. 2000 Yılı Sonrasını Kapsayan Dönem}

2000'li yıllardan sonra yapılan göçler daha çok eğitimli ve nitelikli işgücüne duyulan ihtiyaçtan kaynaklı yapılan göçler oluşturmaktadır. $\mathrm{Bu}$ gruptaki insanların sosyo-ekonomik düzeyleri önceki göçmenlere göre daha yüksektir. Önceki yıllarda oluşan yoksulluk ve işsizlikten kaynaklı göçler bu dönemde çok azalmıştır (Koyuncu, 2015, s. 49).

Türkiye İstatistik Kurumu'nun 2 Ekim 2011 tarihinde yaptığ1 "Nüfus ve Konut" araştırması sonucuna göre yapılan değerlendirmelerde, iller arasındaki bir yıllık göç kapsamında göç eden 2.207.844 kişinin, iller arası göç etme nedenleri olarak ilk beş sırayı; hanedeki fertlerden birine bağlı yapılan $(\% 41,5)$, eğitim amacı ile yapılan $(\% 22,6)$, tayin-atama ile yapılan $(\% 13,4)$, iş arama amacıyla yapılan $(\% 12,2)$ ve evlilik/boşanma ile yapılan $(\% 7,5)$ göçler almaktadır (TÜİK, 2016a). Bu sonuç; 2000 yılı genel nüfus sonuçlarına göre yapılan değerlendirmeye göre göçmen ağlarının etkisi ile yapılan hanedeki fertlerden birine bağlı yapılan göçler ile eğitim amacıyla yapılan göçlerin arttığını, iş arama amacıyla yapılan göçlerin ise azaldığını göstermektedir.

2007-2015 yılları nüfus kayıtları ADNKS esaslarına göre hesaplanmakta olup, 2007-2015 döneminde aldığı göçten daha fazla göç veren iller arasında, Kars ili ilk sırada olmak üzere, Ağrı, Muş, Yozgat, Bayburt, Ardahan ve Bitlis illeri, en fazla gö̧̧ alan illeri de Tekirdağ, Eskişehir, Gümüşhane, Kocaeli, Karabük, Yalova, Çanakkale ve Antalya gibi iller oluşturmuştur. İstanbul, Ankara, Bursa, İzmir metropol illeri önceki dönemlere göre yoğunluğu azalmakla birlikte göç almaya devam etmektedir. Tekirdağ ve Antalya gibi sahil illeri göç almaya, Kars gibi doğuda bulunan iller göç vermeye devam etmektedir. Mersin, Adana ve 
Hatay gibi sahil illeri öncesinde verdiğinden daha fazla göç alırken, artık aldığından daha fazla göç vermeye başlamışlardır. Kocaeli 1999 depreminden sonra nüfus hızı sıfira yakın gerçekleşmişken, 2007-2015 yılları arasında da verdiğinden daha fazla göç alan iller arasına tekrar girmiştir. Kocaeli de metropol illere yakın oluşu buna neden olmuştur (TÜIK, 2016a).

Türkiye'de iç göçleri etkileyen faktörlerin belirlenmesi maksadıyla, 2009 yılına ait 81 ilin net göç oranları ile sosyoekonomik göstergelerin analiz edilmesi sonucunda; "2009 yılı net göç hızı bağımlı değişken alınarak yapılan sıralı regresyon analizi sonucunda kullanılan bağımsız değişkenlerden okuryazar nüfus oranı, yıllık nüfus artış hızı ve on bin kişi başına düşen traktör sayısı değişkenleri” anlamlı bulunmuştur. Sonuçta; sosyo-ekonomik yönden gelişmiş illerin hâlâ göç aldığı tespit edilmiştir (Uysal ve Aktaş, 2011, s. 199).

Göç eden bireylerin göç etme kararını vermede neden olan faktörlerin tespitine ilişkin bir araştırmada; "bireylerin göç kararlarını verirken, alternatif varış noktalarındaki ekonomik firsatlardan ziyade, göç neticesinde ulaşacakları potansiyel geliri dikkate aldıkları" tespit edilmiştir (Topbaş ve Tanrıöver, 2009, s. 103).

2000'li yıllarla birlikte artık insanlar hayatları boyunca çok sık yer değiştirmek zorunda kalmaktadırlar. Özellikle memurlar ve mevsimlik işçiler dönemsel olarak ülke içinde yer değiştirmek zorunda kalmakta, yani devamlı bir göç süreci yaşamaktadırlar. Bu kavrama "yaşam güzergâhları" denilmektedir (Adıgüzel, 2016, s. 37; Tekeli, 2016, s. 171-185). Son y1llarda da kentlerden köylere doğru olan tersine göçler yaşanmaktadır.

Çalışmanın bundan sonraki bölümünde iç göçlerin toplumsal yapıda neden olduğu değişimler incelenecektir.

\section{5. İÇ GÖÇLERIN TOPLUMSAL YAPIDA NEDEN OLDUĞU DEĞişisiM}

Yılmaz (2014, s. 1692), genel olarak göçlerin yarattığı etkiyi; "ister sonuç olarak isterse neden olarak nitelendirilsin veya hangi amaçla yapılırsa yapılsın göç, herhangi bir şekilde bağlı olduğu toplumda sosyal, ekonomik ve politik etkiler bırakmaktadır." şeklinde açıklamıştır. Adıgüzel (2016, s. 2), göçün toplumsal yapıyı etkilemesini; "göç; hem göç veren hem de göç alan yerleşim yerindeki bütün toplumsal yapıyı derinden etkiler." şeklinde belirtir.

İçduygu ve Sirkeci (1999, s. 250) ise göçün yarattığı etkiyi sonuç ve neden ekseninde açıklar: "Kuşkusuz, toplumların tarihsel gelişiminden çıkartacağımız en temel bulgulardan birisi de, göçün toplumsal ve ekonomik dönüşümlerin bir sonucu olarak ortaya çıktığıdır; bu anlamda göç; bir sonuçtur. Bu arada göçün kendisinin de toplumsal ve ekonomik dönüşümlere katkıda bulunan bir etken olduğu unutulmamalıdır; bu çerçevede göç bir nedendir."

İç ve dış göçlerin bir ulusun inşası ve toplumsal değişime olan etkisini gösteren tanımı ise, İçduygu vd. (1998, s. 208-209) şu şekilde belirtmişlerdir: "Modern Türkiye bir anlamda iç ve dış göçlerle inşa edilmiştir. Ulusal inşa döneminde, yeni ülkenin sınırları dışında kalmış bazı Türk ve Müslüman kökenli topluluklar getirilmiş ve yeni Türk ulusunun temellerine eklenmiştir. Gerek bu toplulukların ülke içindeki yerleşimleri, gerekse de sanayileşmeyle birlikte ortaya çıkan kırdan kente göç olgusu bu topraklarda sürekli bir göç olgusu ile birlikte yaşama zorluğu getirmiştir. Hızlı toplumsal değişimin bir sonucu olarak ortaya çıkan göç, paralelinde bir toplumsal değişime de neden olmuştur."

Sosyal bilimler açısından - sosyoloji ve sosyal antropoloji gibi - göçler; kişileri yeni bir topluluğa götüren nedenlerle açığa çıkan yeni uyum sorunlarıyla karşı karşıya kalınması gibi etmenler yönüyle önem kazanmaktadır (Tekeli, 1998, s. 10). Erdentuğ (1980, s. 6) modernleşme çabalarında, kalkınma programlarında, kırsal - sağlık, eğitim, veteriner, tarım, her tür teknik vb. - alanlarda, iç göçün neden olduğu gecekondu bölgeleriyle sanayi kesimlerindeki uygulamalarda sosyal antropolojinin rehberliğine ihtiyaç olduğunu belirtmiştir. Göç araştırmalarında; kantitatif araştırmaların yanında, özellikle kalitatif araştırmalar önem kazanmaktadır. Sosyal antropologların; alan araştırması esnasında olayın içine girmesi, doğru soru sorabilmesi ve cevapları doğru olarak yorumlayabilmesi önem kazanmaktadır (Erkman, 1998, s. 61).

Türkiye'de yaşanan iç göçlerin toplumsal yapıda neden olduğu değişimler; sosyologlar, sosyal antropologlar ve diğer araştırmacıların yaptıkları araştırmalar, belli başlı örnekler verilerek incelenecektir. Bu örnekler göç alan ve göç veren yerde neden olan değişimler şeklinde iki başlık altında da verilebilirdi ama kültürel değişimin iki toplumu da etkileyen ve birbirine girmiş yapısı nedeniyle, değişim tek bir başlık altında verilmiş̧ir.

\section{1. İç Göçlerin Göç Alan ve Göç Veren Yerde Neden Olduğu Değişim}

Engelbrektsson (1978, s. 94-95), 1940 yıllarından itibaren Konya Alihan'da aile nüfuslarının artması ve toprak yetersizliği 
nedeniyle özellikle fakir ailelerden erkeklerin yılın birkaç ayı köy dışına sezonluk işlerde çalışmak amacıyla çıkmaya başladıklarını belirtmiştir.

İç göçler; 1950 yılları ile birlikte artmaya başlamakla birlikte, öncesinde yukarıda belirtilen mevsimlik göçler yaşanmaya başlamıştır.

Saran (1974), Adana'ya bağlı Kızıltahta köyünde yaptı̆̆ 1 araştırmada; köyde göçün 1949 yılında başladığını, yirmi yılda köy dışında yaşayan nüfusuyla köyde yaşayan nüfusun eşitlendiğini, köyün Adana'ya yakın oluşunun şehirle olan ilişkiyi arttırdığını, şehre göç eden kişilerin köyde başarılı olan kişiler olarak görüldüğünü belirtmiştir.

G. ve B. Helling (1956), insanların yeni iş alanları bulması, tarımda makineleşmeyle eskiden uzak sayılan yerlere yeni ürünlerin ekilmesi, turizmin artması, kentlerin büyümesi ve yaşanan göç ile köy yaşantısının değiştiğini belirmişlerdir (Tütengil, 1983, s. 70-72).

Schiffauer (1993, s. 68-78)'ün, 1977'den 1986 yılına kadar yaptığı araştırmalarda göçün köyde kalanları da değiştirdiğini, ilk aşamada "kırsal-kentsel genişletilmiş hane" oluşturduğunu, aile reisinin ölümüyle bu kurumun dağıldığını ve köyde kalan çocukların bile "köyde istikbal yok" diye kente gitmeyi istediklerini, ama anne-babayı bırakıp gidemediğini belirtmiştir.

İncirlioğlu (1993, s. 121-123) da, Stirling ile yaptığı çalışma sonucunda, Stirling'in 1945-51 yıllarında kadınların evlenme yaşlarını 14-18 olarak belirttiğini, 1986'da da iki köyde yirmi yaşlarında evlenmemiş ve "evde kalmış" olarak değerlendirilen birçok kızın bulunduğunu ve de köyde kalan annelerin artık çocuklarını kente göç etmiş yani köy dışında işi olan veya mesleği olanlara vermek istediğini ortaya koymuştur. Erken yaşta görülen evlilikler yaşanan kültürel değişim sonucu ortadan kalkmakta, anne ve babalar artık kızlarının daha iyi hayat şartlarında yaşamaları için kentlerde yaşayanlarla evlenmelerine tercih etmektedirler.

Yapılan çalışmalarda, göç edenlerin büyük çoğunluğunun, göç etmek için gerekli olan bilgi, kültür ve mali güce sahip olduğudur (İçduygu vd., 1998, s. 208-209). Yapılan başka bir çalışmada da sürekli göç olaylarının genellikle eğitim almış, genç kişilerde görülmesi de bunu desteklemektedir (Oğuz, 2003, s. 125).

İç göçlerin, bir köyde sosyal ve kültürel yapı üzerinde yarattığı değişim ve etkileri Akşit (1998, s. 34) şu şekilde açıklamıştır: "Denizli'nin Honaz ilçesine bağlı Aşağıkaraçay köyü ilçe merkezine 20 kilometre uzaklıkta bir dağ köyüdür. 1970'lerde köye elektrik geldi. 1997 yılından başlayarak köyden 150 genç kız ve erkek köyden 25 kilometre uzaklıkta Denizli'de tekstil fabrikalarına çalışmaya başladılar. Köy, kentin bir mahallesi haline gelmedi. Köy, hala bir köy. Ancak köy ve kent arasındaki fark veya ayrım 1950'ler ve 1960'lardaki açıklı̆̆ kaybetti. Üretim, ulaşım ve haberleşme devrimleri benim köyüme de geldi. Yakın bir zamanda internete bağlanmış bir bilgisayar ve onun başında sanal dünyaya gezintiler yapan bir köylü çocuğunu görürsem pek şaşırmayacağım.” Bu değişim bilgi toplumunun hızlı gelişimi ile günümüzde yoğun şekilde köy ve şehirde yaşanmaktadır.

İç göçlerin kültürel ve ekonomik değişimi hızlandırdığı bilinmektedir. $\mathrm{Bu}$ değişim sadece tek yönlü olarak yaşanmamaktadır. Göç eden bireyin ayrıldığı çevrede daha önce kurmuş olduğu ilişkiler değişirken, yeni yerleştiği çevrede kuracağı ilişkiler de değişikliğe uğrar (Erder, 1986, s. 16).

Stirling (1993, s. 10), Türkiye'de köyden kente göç eden ve yurdun çeşitli yerlerinde yaşayan; geniş ölçüde gelir, eğitim ve statü gruplarında bulunan milyonlarca köylü olduğunu belirtir. Bu köylüler, köylerindeki ilişkilerinden çok farklı sosyal ağlar içinde yaşamakta ve ekonomik büyümelerinde, kimliklerinde, sosyal yapılarında, becerilerinde, bilgi seviyelerinde ve kültürlerinde radikal değişimler yaşamaktadırlar. Bu yaşanan değişimler ister istemez Stirling'in de belirttiği gibi Türkiye'de neredeyse bütün köylerde ve çoğu köy hanesinde, kasabada kazançları olan fertler ile daha önceden göç etmiş ve kasabada oturan fertlerin bulunmasina neden olmuş ve buda köy sosyal bağları ve kimliklerini değiştirmektedir.

Basit, farklılaşmamış ve örgütlenmemiş bir ortam olan köylerden kentlere yapılan göçlerde, köylü göçmenler göç eder etmez birden değişmezler. $\mathrm{Bu}$ değişmeler onların kentte kuracakları yeni ilişkiler sonucu belirli bir süreç içinde gerçekleşir (Erder, 1986, s. 9-10). Göç eden bireyler farklı kültürlerle temas kurarak kültürleşme sürecini yaşamakta ve kültürleme süreciyle köyle bağlantılarını devam ettirmeleri nedeniyle köyde değişimler yaşanmasına sebep olmaktadırlar.

Modernleşme, kentleşme ve maddi olanakların artmasıyla aile bireylerinin karşılıklı bağımlılıkları, ekonomik gelişme sonucu maddi düzeyde azalsa bile duygusal düzeyde devam etmektedir (Kağıtçıbaş1, 1991, s. 34). Bu bağlamda köyden göç etmiş ve kentte yaşayan aile bireyleriyle devam eden bu duygusal bağımlılıkla köyde yaşayanların davranış tarzları, yaşamları, 
konuşmaları, tüketimleri, binaların mimarisi ve iletişimi kent yönünde bir şekil almaktadır (Oğuz, 2003, s. 131). Köyde yapılan modern mimari yapılar, köylerde eskiden satılmayan yeni ürünlerin satılmaya başlanması, köy düğünlerinin yerine kent (salon) düğünlerinin tercih edilmesi, köy ağızlarının zamanla kaybolması gibi örnekler bize bu yaşanan değişimi göstermektedir.

Kent yaşamında özellikle kültürleşmenin etkisiyle kent kültürünün geleneksel kültürleri etkilemesi süreci yaşanır. Bu süreçte göçmenler yaşadıkları kentlerde hemşerilik duygularıyla kendi aralarında bir iletişıim ağı kurmuşlardır. Bu iletişim ağıyla kültür derneklerinin kurulması ve bu derneklerle hem kentte yaşayan hem de köyde yaşayanlarla kültürel bağların kurulması gerçekleştirilmeye çalışılmıştır (Aslan, 1999, s. 30).

Türkiye'de iç göçün neden olduğu kentleşme ve gecekondulaşma, batıda görülen "fakirlik kültürü" ve "getto" anlayışına sahip olmamıştır. Gecekondular kentlerin dışı yerine, kentlerin kenarında oluşturulmuş ve "dinlenme havuzları" olarak isimlendirilmiştir. Göçmenler kentliler ile uyumlaşma sürecinde olmuşlardır. Oluşan hemşerilik kültürü "topluma karşı nefret ve düşmanlık üretmeksizin” toplumsal bağ işlevi görerek göçmenlerin yabancılaşmasını engellemiştir (Kılınç ve Benzi, 2011, s. 327, 341).

Ay (2013, s. 17), iç göçün toplumsal yapıda meydana getirdiği etkileri belirtirken, bazı bölgelerde göç edenlerin kente uyumu sürecinin hâlâ yeterli olmadığını bize göstermektedir: "İç göçler kaynak bölgeyi "hayalet şehir" haline getirebilmekte, hedef bölgede gecekondulaşma, işsizlik, kültürel boşluk ve gettolaşmaya sebep olmakta, şiddet olaylarını, özellikle de mala karşı suçları artırmakta ve mafya gibi yapılanmalara neden olmakta, ayrıca göç edenlerin kendilerinin de ruh sağlığının bozulması sonucunu yaratmaktadır."

Göçler, 1990 yıllarından itibaren artık kentten (şehirden) köye oluşacak şekle dönüşmeye başlamıştır. Bu dönüşüm özellikle sosyal güvenlik sistemlerinin ülkede oturması sonucu yaşanmıştır. Bu göçleri Tekeli "geriye dönüş" göçleri olarak belirtmiştir: "Yaşam döngüsünün sonuna gelmiş emeklilik aşamasına girmiş kişilerin güdüleri ve gerçekleştirmeye çalıştıkları şeyler ise değişecektir. Göçleri iş firsatlarının yoğun olduğu yerlerden çok, iklimi ve doğa koşulları iyi olan yerlere yönelecektir. Bazı hallerde geriye dönüş göçleri ortaya çıkacaktır" (Tekeli, 1998, s. 15). Bu yeni oluşum ilk başlarda belki yazları ve bayramlarda tercih edilecek olmakla birlikte, ileride emeklilik sonucu devamlı kalınacak yer olarak tercih edilebilecektir.
Bir sonraki bölümde iç göçün meydana getirdiği sorunlar ile bazı araştırmacıların çözüm önerileri incelenecektir.

\section{6. İÇ GÖÇÜN MEYDANA GETIRDIIĞİ SORUNLAR VE ÇÖZÜM ÖNERILERI}

Kalkınmakta olan ülkeler, 1992 y1lında dünya nüfusunun \%77'ini oluştururken, bu oran 2025 yılında \%85'e çıkacaktır. Dünya'da 1900 y1lında 1 milyonu geçen 16 kent varken, 1990 yılında 1 milyonu geçen kent sayısı 276'ya, 2015 yılında 10 milyonu geçen kent sayısı 29'a, nüfusu 5-10 milyon arasında olan kent sayısıysa 44'e çıkmış, 2025 'te dünya nüfusunun \%60'1 kentli olacaktır. Dünya nüfus artışı gelişmekte olan ülkelerde yoğunlaşacaktır. Kentsel nüfus artışının neden olduğu çarpık kentleşme ve "gecekondulaşma"; suç oranları ile hava, su ve gürültü kirliliğinde artışa neden olacaktır (Stevens, 1992; aktaran Kottak, 2002, s. 544). 2016 yılı nüfus sayımına göre Türkiye nüfusun $\% 92,3$ 'ü il ve ilçe merkezlerinde (kentlerde) yaşamaktadır. Yapılan nüfus projeksiyonlarına göre; Türkiye'nin 2023 y1lı nüfusu 84.247.088'e yükselecek, yaşlı nüfus olarak tabir edilen 65 yaş üstü nüfus \%7,5'den, \%10,2'ye yükselecektir. Türkiye'nin nüfus artışının 2050 yılına kadar devam edeceği öngörülmektedir (TUIK, 2013). Yukarıda Dünya'da belirtilen sorunlar ülkemizde de yaşandığına göre, yapılan nüfus projeksiyonları da ileride belirtilen sorunların yaşanmaya devam edeceğini bize göstermektedir.

Türkiye'de yaşanan iç göçler nedeniyle, gerek köylerde, gerekse kentlerde değişimler meydana gelmektedir. Köy ve kent kültürlerinde göç nedeniyle değişimler yaşanmış ve halen de yaşanmaya devam etmektedir. Bilinen köy ve kent kültürleri zamanla değişmiş ve yeni sentezlerin doğmasına neden olmuştur. $\mathrm{Bu}$ değişimlerin sonucunda doğal olarak bazı sorunlarda yaşanmış ve yaşanmaktadır. Göçün meydana getirdiği sorunların bir kısmına makalenin ilgili bölümlerinde değinilmiştir. Sorunlar; siyasi, sosyal, kültürel ve ekonomik olarak sinıflandırılabilir. Aşağıda sınıflandırma ve önem derecesi göz önünde bulundurulmadan, köylerde ve kentlerde yaşanan sorunların tümü olmasa da önemli bir kısmı özetlenmiştir:

Kentlerde yaşanan sorunlar; hızla artan sanayileşme sonucu, yaşanan çarpık/aşırı kentleşme ve gecekondulaşma, gecekondulaşma ve sağlıksız yapılaşmanın yaşanan depremlerle aşırı can kaybına neden olması, yanlış arazi kullanımı, imar sahası dışında yer alan tarım alanlarının zamanla konut alanlarının baskısı altında kalarak imara açılması, kaynakların kentleşmeye orantılı kullanılmaması, kentlerde suç oranlarının artması (özellikle hırsızlık, madde bağımlılığı, cinsel istismar 
vb.), sağlık, eğitim, istihdam sorunları yaşanması, kentlere gelen göçmenlerin kayıt-dışı ikincil ekonomik sektöre yönelmeleri, özellikle kentlerde çevresel sorunlarının yaşanması, plansız yapılaşmanın sonucunda altyapı yetersizlikleri yaşanması, göçmenlerin; kültürel uyum sorunları ile psikolojik sorun yaşamaları, işsizlik ve yoksullukla sokakta yaşayan insanların sayısının artması, bölgeler arasında dengesizliğin artmasıdır.

Köylerdeki yaşanan sorunlar ise; köy nüfuslarının hızla azalması, köy ekonomisinin şekil değiştirmesi, tarım ve hayvancılı̆̆ın azalması, genç ve girişimci nüfusun kaybedilmesi, evlilik tercihleri ile köy yaşamının/yaşantısının değişmesidir.

Aşağıda iç göçlerin yönetilebilmesi ile iç göçlerin neden olduğu sorunların çözüm noktasında şimdiye kadar yapılan çözüm önerilerinden bazıları özetlenmiştir:

Yamak ve Yamak (1999, s. 27), Türkiye'nin 67 ilinin 19801990 yılları net göç oranları ile gelir rakamları incelenmesi sonucunda gelir ile göçün birbirine bağımlı olduğunu, çözüm noktasında ise; "yöresel gelir dengesizliğinin en azından kısa dönemde korunması ve uzun dönemde de iyileştirilmesi gerekmektedir. Bu da, ancak yapılacak kamu ve özel yatırımların büyük bir kısmının net göç veren yörelere taşınmasını teşvik edecek etkin politikaların uygulanmasıla mümkündür." şeklinde belirtmiştir. 2014-2015 dönemi verilerine göre net göç hızı eksi olan (nüfusuna göre aldığından daha fazla göç veren) iller Ağrı, Muş, Kars, Bitlis, Hakkari, Çankırı, Şırnak, Ardahan, Siirt, Yozgat ve Bayburt, net göç hızı artı olan (nüfusuna göre verdiğinden daha fazla göç alan) illerse Antalya, Kocaeli, Tekirdağ, Ankara, Eskişehir, Kastamonu ve Yalova olmuştur. Güncel veriler de illerin geliri ile göçün birbirine bağımlı olduğunu büyük oranda göstermektedir.

Çelik (2007, s. 103), "göç veren yerleri ekonomik, sosyal ve kültürel bakımdan göç alan yerlerin konumuna yaklaştırıcı politikaların belirlenip uygulanması" gerektiği üzerinde durmuştur. Sarı (2008, s. 17), Ülke kaynakların adaletli dağıtılmasını, geri kalmış yörelere yönelik yatırımlara ağırlık verilmesini, Kocadaş (2016, s. 15) "göç veren ve göç alan bölgelerde ekonomik yönden bir gelişme sağlanması gerektiğini”, Uysal ve Aktaş (2011, s. 199) da, yine benzer bir şekilde köyden kente olan iç göçün çözümünde; "tarım ve hayvancılıkta yapılacak teşvik ve diğer sosyal ve mali yardımlar göç oranının makul seviye çekecek girişimlerden olacaktır." şeklinde belirtmişlerdir.

Gökulu (2011, s. 224), kentleşme sorunu bağlamında, yönetim anlayışı çerçevesinde; "sosyal devlet anlayışının hâkim olduğu, çöküntü bölgelerine yönelik sosyal dışlanmanın ve fiziki yetersizliklerin ortadan kaldırıldığı bir yönetim anlayışı, suç oranlarını azaltacak ve kentleşmenin her zaman için suçu artıran bir kavram olarak algılanmasının önüne geçecektir." şeklinde öneride bulunmuştur.

Özdemir (2012, s. 15), işsizlik ve yoksulluk yaşayan, ekonomik bakımdan geri kalmış bölgelere kamu ve özel kesimce uygun yatırımlar yapılması ile buralarda istihdam alanlarının oluşturulması gerektiğini, kalkınmada öncelikli illerin sayısının arttırılmasını, köylerin organik tarım, eko-turizm ve kooperatifleşmesi gibi tedbirler ile kalkındırılmasını, kentlere göçle gelenlerin kentlileşme düzeylerinin yükseltilmesini, derneklerin kurulmasını, altyapısı oluşturulmuş alanlar oluşturulmasını önermiştir.

Sertkaya-Doğan (2015, s. 18), iç göçü durdurmak veya yavaşlamak için atılması gereken tedbirleri; kırsal alanların geliştirilmesi, sürdürülebilir kırsal kalkınma projeleri oluşturulması ile kırsal alanlardaki insanların gelirlerinin artırılması ve onların köylerde kalmalarının sağlanacağını önermektedir. Bununla birlikte; "birim alanından en iyi şekilde yararlanabilmek için tarım ağırlıklı yöntemlerin uygulanmasını, hayvancılığın yaygınlaştırılmasını, kırsal alanlardaki tarımsal sanayi tesislerinin sayısının artırılmasını ve bunun için kredi verme gibi gerekli teşviklerin sağlanmasını, kırsal alanlardaki sağlık, eğitim ve ulaşım hizmetlerinin iyileştirilmesi” önermiştir.

Güneş (2013, s. 300), iç göçün nedenlerinden olan terör sebebiyle yaşanan sorunların çözüm noktasında; mücadelenin sadece güvenlik temelli ele alınmamasını, soruna kapsamlı bakış açısı ile yaklaşılmasını önermiştir.

Ay (2013, s. 51-52)'ın çözümü hem göç alan hem de göç veren bölgelere yönelik olmuştur. Göç veren yerleşim yerlerinde nüfus hareketlerini azaltılmasını ve göç veren bölgelerde yer alan küçük şehir ve ilçelerin iş, eğitim ve sağllğa erişim vb. imkânları barındıran birer cazibe merkezi haline getirilmesini, göç alan yerleşim yerlerinde ise, devletin tüm kurumları ve sivil toplum kuruluşlarının, göçmenlerin kente uyum sağlaması için işbirliği yapmalarını önermiştir.

Çelik ve Murat (2014, s. 38); il yöneticilerin stratejik bilince sahip olmasını, göç veren ilin iç ve dış çevre analizinin yapılmasını, misyon ve vizyon çerçevesinde stratejilerin belirlenmesini, uygulama aşamasında ise diğer aktörlerin (sivil toplum örgütleri, odalar, belediyeler, üniversiteler, valilik ve kaymakamlıklar vb.) katılımının sağlanması gerektiğini belirtmişlerdir. 
Bulut ve Eraldemir (2015, s. 36), iç göçün yerleşilen yerlerde değişim ve dönüşüme neden olduğunu, bu durumun "bütünleşme süreciyle desteklenmesi, entegrasyonu beraberinde getirmesi, göçle ortaya çıkan sorunların çözümü aşamasında kamu yönetimlerin önemli bir rol üstlenmesi” gerektiğini belirtmişlerdir.

Çakır (2011, s. 140), 50-60 yıldır göç sorunu üzerinde birçok çalışma yapıldığını ama bir yararı olmadığını belirtmiştir. Ayrıca; "sosyal bilimciler, uzmanlar göçün durdurulabilir olduğunu ya da göçenlerin bir gün geri döneceklerini sağlayacak politikaların neler olması gerektiğini tartışarak bugüne gelinmiştir." şeklinde bir eleştiride bulunmuş, çözüm noktasında ise; "göçenlerin yaşamsal sorunlarını nasıl çözeceğimizi düşünüp ona göre öneriler ve uygulamalar yapmalıyız." şeklinde öneride bulunmuştur.

İç göçün azaltılması veya göçmenlerin geriye dönüşü noktasında alınacak önlemlerden olan; bölgeler veya yerleşim yerleri arasında gelir dengesinin iyileştirilmesi ile kentlerin çekici ve köylerin itici etkilerinin azaltılmasını öneren çözümlerin günümüz şartlarında pek geçerli görülmemektedir. Son resmi kayıtlara göre, Türkiye nüfusun $\% 92,3$ 'ünün il ve ilçe merkezlerinde yaşadığı göz önünde bulundurulduğunda, kentlerde yaşanan ve yukarıda belirtilen sorunların çözüm noktasında; göçmenlerin kente uyumları sağlanmalı ve bu maksatla stratejiler belirlenmeli, birçok aktörün katılımı ve bütüncül bir yaklaşım ile yaşanan sorunlara çözüm bulunmalıdır.

\section{SONUÇ}

Türkiye; İkinci Dünya Savaşı'na kadar kırsal alanda yoğunlaşmış ve tarımla uğraşan bir ülke iken, savaş sonrasında hızla artan bir sanayileşme ve kentleşme süreciyle birlikte iç göçle karşıllaşmıştır. Bu süreçle; köyden kente olan yoğun göç yeterli endüstri olmaması nedeni ile kentleşmenin sanayileşme olmadan gerçekleşmesine neden olmuştur. Sanayileşmeye başlayan Türkiye köyden kente gelen göçmenleri barındırabilecek konut ve onlar için yeterli istihdam sağlayamamış "gecekondulaşma" ile "kayıt-dışı ikincil ekonomik sektörün" oluşmasına engel olamamıştır. Sonuçta; Türkiye çarpık/aşırı kentleşme ile karşı karşıya kalmıştır.

Bilgi toplumuna geçişle birlikte özellikle nüfusun büyük bir oranı kentleşmiş, insanların hareketliliği hızlanmış, dolayısıyla insanlar daha sık yer değiştirmeye başlamıştır. Artık insanlar belli bir yere bağlı olamamakta ve yaşamları boyunca hareket halinde olmaktadırlar. Türkiye'de iç göçler devam etmektedir. Günümüzde iç göçler, denetimsiz ve gönüllü bir hale gelmiştir. Mevsimlik işçilerin gerçekleştirdiği dönemsel göçler, memurların atanması nedeniyle yapılan göçler, inşaat sektöründe çalışan işçilerin kentlere yaptıkları iç göçler zaten devam eden iç göçlerden sadece bazılarını oluşturmaktadır. Dünya'da ve ülkemizde ekonomik sebeplerin başında olan işsizlik ve yoksulluk ile bölgeler arası dengesiz gelir dağılımı devam ettikçe, güvenlik ve terör sorunları da oldukça iç göçler mutlaka olacaktır. Türkiye'nin güneyindeki komşu ülkelerde yaşanan siyasi istikrarsızlıklar ile çatışmaların varlığı da sınır illerinden kuzey veya batı illerine de azda olsa iç göçün yaşanmasına neden olmaktadır.

Türkiye'de yaşanan göç hareketleri; çeşitleri, sebepleri ve yarattığı kültürel, ekonomik ve siyasal sebepleriyle pek çok araştırmaya konu olmaya devam etmektedir. Son yıllarda ise "kentten köye" olan ters göçün yani "geriye dönüş" göçlerinin veya "emeklilik göçlerinin” artmasıyla göçlerin köylerde meydana getirdiği sosyal, ekonomik ve kültürel değişimler köylerde yapılacak araştırmalarla tespit edilmelidir.

Türkiye'nin göç alanındaki politikalarını düzenlemek ve göçü daha etkin yönetmek için; 6458 sayılı Yabancılar ve Uluslararası Koruma Kanunu çıkarılmış olup, bu kanunla İçişleri Bakanlığı'na bağlı Göç İdaresi Genel Müdürlüğü kurulmuştur. Türkiye'deki üniversitelerde göç araştırmaları ile Göç Araştırma Merkezleri kurulmaya başlanmıştır. Hacettepe Üniversitesi Nüfus Etütleri Enstitüsü; 1968'den beri genel Nüfusbilim çalışmaları kapsamında göç konusunda çalışmalar yürüten en eski akademik merkezdir. Göç Araştırma merkezlerden birincisi Bilgi Üniversitesi bünyesinde kurulmuştur. Yakın dönemde de Hacettepe Üniversitesi'nde Siyaset ve Göç Araştırmaları Merkezi (HÜGO), Manisa Celal Bayar Üniversitesi'nde Nüfus ve Göç Araştırma Merkezi, Gediz Üniversitesi'nde Göç Araştırmaları Merkezi (MiREG), Türkiye ve Orta Doğu Amme İdaresi Enstitüsü (TODAİE) İnsan Hakları, Vatandaşlık ve Göç Çalışmaları Merkezi ve Celal Bayar Üniversitesi'nde Nüfus ve Göç Araştırmaları ve Uygulama Merkezi (NÜ-GAM) gibi merkezler kurulmuştur.

Karar alıcı olan kamu ve yerel yöneticilerin, sivil toplum örgütleri ile üniversitelerin desteğini alarak, çalışmada ayrıntısıyla belirtilen iç göçe neden olan olayları, iç göçün meydana getirdiği sorunları (çarpık kentleşme, gecekondu, yoğun trafik, yoksulluk, işsizlik, suç oranlarında artış vb.) ve göçmenlerin uyumunu; önümüzdeki yıllarda da devam edecek olan iç göç süreçlerini yönetmeleri açısından dikkate almaları gereken en önemli nokta olacaktır. Bu süreçte yöneticilerin; göç araştırma ve uygulama merkezlerini, Göç İdaresi Genel Müdürlüğ̈̈’nü, sosyal bilimcileri göç sorunlarının tespiti ve giderilmesinde etkin olarak kullanmaları gerekecektir. 


\section{KAYNAKLAR}

Abadan-Unat, N. (2002). Bitmeyen göç: Konuk işçilikten ulus-ötesi yurttaşlı̆̆a. İstanbul: Bilgi Üniversitesi Yayınları.

Adıgüzel, Y. (2016). Göç sosyolojisi (1.bs). Ankara: Nobel Akademik Yayıncılık.

Akkayan, T. (1979). Göç ve değişim. İstanbul: Edebiyat Fakültesi Yayınları Basımevi.

Akşit, B. (1999). Cumhuriyet döneminde Türkiye köylerindeki dönüşümler. O. Baydar (Ed.), 75 Yılda köylerden şehirlere içinde (s. 173-186). İstanbul: Tarih Vakfi Yurt Yayınları.

Akşit, B. (1998). İçgöçlerin nesnel ve öznel toplumsal tarihi üzerine gözlemler: Köy tarafından bir bakış. Türkiye'de içgöç, Bolu-Gerede, 6-8 Haziran 1997 içinde (s. 22-37). İstanbul: Tarih Vakfı Yayınları.

Aslan, C. (1999). Türkiye Çerkeslerinde sosyo-kültürel değişme. Türkiye Çerkeslerinde sosyo-kültürel değişme içinde (s. 25-32). Ankara: Kaf Der Yayınları.

Ay, Y. (2013). İç göçlerin emniyet ve asayişe etkisi. Güvenlik Bilimleri Dergisi, 2(1), 35-56.

Bergman, E. F. (1995). Human geography: Cultures, connections, and landscapes. New Jersey, NJ: Prentice Hall.

Brettell, C. B., \& Hollifield J. F. (2000). Migration theory: Talking across disciplines. (pp. 1-26). New York, London: Routledge.

Brettell, C.B. (2000). Theorizing migration in anthropology: The social construction of networks, identities, communities, and globalscapes". In C. B. Brettell \& J. F. Hollifield (Eds.), Migration theory: Talking across disciplines (pp. 97-135). New York: Routledge.

Bulut, Y. ve Eraldemir, Z. (2015). Göç olgusunun farklı boyutlarıyla Hatay ili İskenderun ve Dörtyol ilçeleri ölçeğinde incelenmesi. Y. Bulut (Ed.), Uluslararası göç ve mülteci sorununun çözümünde kamu yönetiminin rolü. Kocaeli: Umuttepe Yayınları.

Çakır, S. (2011). Geleneksel Türk kültüründe göç ve toplumsal değişme. SDÜ Fen Edebiyat Fakültesi, Sosyal Bilimler Dergisi, 24, 129-142.

Çelik, N. ve Murat, G. (2014). Türkiye'de iç göç sorununa yeni bir yaklaşım: Stratejik iç göç yönetimi, İstanbul Üniversitesi Işsletme İktisadı Enstitüsü Dergisi, 76, 18-44.

Çelik, F. (1999). Ekonomik yönleriyle iç göç olgusu (teori ve uygulama). (Yayınlanmamış Yüksek Lisans Tezi). Erciyes Üniversitesi Sosyal Bilimler Enstitüsü, Kayseri

Çelik, F. (2007). Türkiye'de iç göçler: 1980-2000. Erciyes Üniversitesi Sosyal Bilimler Enstitüsü Dergisi, 22(1), 87-109.

Doğan, M. (2013). Nüfus politikalarının Dünyada ve Türkiye'de uygulanma süreçleri. Dernekler Dergisi, 2, 20-29.

Doğan, M. (2011). Türkiye'de uygulanan nüfus politikalarına genel bakış. Marmara Coğrafya Dergisi (ISI), 23, 293-307.

Doğan, M. (2005). Türkiye ziraatinde makineleşme: Traktör ve biçerdöverin etkileri. Coğrafya Dergisi (ISI), 14, 66-75.

Engelbrektsson, U.B. (1978). The force of tradition: Turkish migrants at home and abroad. Goteborg: Acta Universitatis Gothoburgensis.
Erdentuğ, N. (1980). Niçin ülkemizde "sosyal antropoloji” bilimine ihtiyaç vardır. Ankara Üniversitesi Dil ve Tarih Coğrafya Fakültesi Antropoloji Dergisi, 12, 5-8.

Erder, S. (1986). Refah toplumunda "getto" ve Türkler. İstanbul: Teknografik Matbaacılık A.Ş.

Erkman, T. (1998). Göç olgusunda kalitatif yöntem olarak etnografik araştırma: Bir gecekondu araştırmasının düşündürdükleri. Türkiye'de içgöç, Bolu-Gerede, 6-8 Haziran 1997 içinde (s. 56-66). İstanbul: Tarih Vakfi Yayınları.

Gökulu, G. (2011). Kent güvenliği kentleşme ve suç ilişkisi. Atatürk Üniversitesi İktisadi ve İdari Bilimler Dergisi, 24(1), 209-226.

Görmez, K. (1997). Kent ve siyaset. Ankara: Gazi Kitabevi Yayınlar1.

Güneş, M. E. (2013). İç göç terörizm ilişkisinde mersin örneği. Akademik Incelemeler Dergisi, 8(2), 275-302.

Gürsoy, A. (1998). Göç. U. Tanyeli (Ed.), Üç kuşak Cumhuriyet içinde (s. 60-68). İstanbul: Türkiye Ekonomik ve Toplumsal Tarih Vakfi Yayını.

Güvenç, B. (2002). İnsan ve kültür. İstanbul: Remzi Kitabevi.

Helling, G. ve Helling, B. (1956). Sosyolojik ve istatistiki bakımdan Türkiye'de köy (Çev. A. E. Uysal). Ankara: Başbakanlık İstatistik Umum Müdürlüğü (DİE) Yayını.

İçduygu, A., Erder, S. ve Gençkaya, Ö. F. (2004). Türkiye'nin uluslararası göç politikaları: 1923-2023, İstanbul: Koç Üniversitesi Göç Araştırmaları Merkezi.

İçduygu, A. ve Sirkeci, İ. (1999). Cumhuriyet dönemi Türkiye'sinde göç hareketleri. O. Baydar (Ed.), 75 yılda köylerden şehirlere içinde (s. 249-268). İstanbul: Tarih Vakfi Yurt Yayınları.

İçduygu, A. ve Ünalan, T. (1998). Türkiye'de içgöç: Sorunsal alanları ve araştırma yöntemleri. A. İçduygu (Ed.), Türkiye'de içgöç konferans Bolu-Gerede, 6-8 Haziran 1997 içinde (s. 38-55). İstanbul: Tarih Vakfi Yurt Yayınları,.

İçduygu, A., Sirkeci, İ. ve Aydıngün, İ. (1998). Türkiye'de içgöçün işçi hareketine etkisi. A. İçduygu (Ed.), Türkiye'de içgöç konferans Bolu-Gerede, 6-8 Haziran 1997 içinde (s. 207-249). İstanbul: Tarih Vakfi Yurt Yayınları.

İncirlioğlu, E. O. (1993). Marriage, gender and rural transformation in central anatolia. In P. Stirling (Ed.), Culture and economy: Changes in Turkish villages. London: The Eothen Press.

Kağıtçıbaşı, Ç. (1991). Insan aile kültür. İstanbul: Remzi Kitabevi.

Karpat, K. H. (2015). Önsöz. Türkiye'nin göç tarihi 14.yüzyıldan 21.yüzyıla Türkiye'ye göçler. İstanbul: İstanbul Bilgi Üniversitesi Yayınları.

Karpat, K. H. (2003). Türkiye'de toplumsal dönüşüm, kırsal göç, gecekondu ve kentleşme, (A. Sönmez, Çev.). İstanbul: İmge Kitabevi.

Kılınç, Z. A. ve Benzi, B. (2011). Kentleşme, gecekondu ve hemşerilik. Akademik Incelemeler Dergisi, 6 (2), 323-344.

Kocadaş, B. (2016). Cumhuriyet döneminde yapılan iç ve diş göçler'in toplumsal etkileri. Sosyolojik Düşün Dergisi, 1(1), 11-18. 
Kottak, C. P. (2002). Antropoloji: Insan çeşitliğine bir bakış. Ankara: Ütopya Yayınevi.

Koyuncu, A. (2015). Kentleşme ve göç. İstanbul: Hikmetevi Yayınları.

Lee, E.S. (1969). A theory of migration. In J.A. Jackson (Ed.), Migration. London: Cambridge University Press.

Oğuz, K. (2003). Türkiye'de içgöçün kırsal alanda yarattı̆̆ değişim: Içel-Melleç kırsal (Demirören) köyü örneği. (Yayımlanmamış Yüksek Lisans Tezi). Yeditepe Üniversitesi Sosyal Bilimler Enstitüsü, İstanbul.

Özdemir, H. (2012). Türkiye'de iç göçler üzerine genel bir değerlendirme. Akademik Baklş Dergisi, 30, 1-18.

Özcan, Y. Z. (1998). İçgöçün tanımı ve verileri ile ilgili bazı sorunlar. Türkiye'de içgöç konferans Bolu-Gerede, 6-8 Haziran 1997 içinde (s. 78-90). İstanbul: Tarih Vakfi Yayınları.

Perruchoud, R. (Ed.). (2009). Göç terimleri sözlüğü [No:18] (Çev. B. Çiçekli). Cenevre: Uluslararası Göç Örgütü.

Peker, M. (1999). Türkiye'de içgöçün değişen yapısı. O. Baydar (Ed.), 75 yılda köylerden şehirlere içinde (s. 295-304). İstanbul: Tarih Vakfı Yurt Yayınları.

Petersen, W. (1996). A general typology of migration. In C.J. Jansen (Ed), Readings in the sociology of migration, New York: Pergamon Press.

Saran, N. (1974). Antropoloji ve köy toplumları. Sosyoloji Konferansları Dergisi, 12, 77-100.

Sarı, A. (2008). Türkiye'de iç göç: Fiziksel, sosyal ve ekonomik sonuçları. Sosyoloji Konferansları Dergisi, 37, 1-18.

Schiffauer, W. (1993). Peasants without pride: Migration, domestic cycle and perception of time. In P. Stirling (Ed.), Culture and economy: Changes in Turkish villages (pp. 65-79). England: The Eothen Pres.

Sertkaya-Doğan, Ö. (2015). Population movements in Turkey internal migration. In H. Arslan, M. A. İcbay and S. M. Stranciu (Eds.) Contemporary studies in humanities (pp. 18-29). Mannheim: Ehrmann Verlag.

Stevens, W.K. (1992, May 5). Humanity confronts its handiwork: An altered planet. The New York Times, B5-B7.

Stirling, P. (1993). Growth and changes: Speed scale complexity. In P. Stirling (Ed.), Culture and economy changes in turkish villages (pp. 65-79). England: The Eothen Pres.

Tekeli, İ. (2016). Türkiye'de içgöç sorunsalı yeniden tanımlanma aşamasına geldi. İ. Tekeli (Ed.), Göç ve ötesi içinde, (s. 171-185) (2.bs). İstanbul: Tarih Vakfi Yurt Yayınları.
Tekeli, İ. (1998). Türkiye'de içgöç sorunsalı yeniden tanımlanma aşamasına geldi. A. İçduygu (Ed.), Türkiye'de içgöç konferans Bolu-Gerede, 6-8 Haziran 1997 içinde (s. 7-21). İstanbul: Tarih Vakfi Yurt Yayınları.

Tekeli, İ. ve Erder, L. (1978). Yerleşme yapısının uyum süreci olarak içgöçler. Ankara: Hacettepe Üniversitesi Yayınları.

Temurçin, K. ve Sargın, S. (2011). Türkiye’nin suç coğrafyası-şehir asayiş suçları. Ankara: Polis Akademisi Yayınları.

Tezcan, M. (2008). Toplumsal bilimlere giriş. Ankara: Anı Yayıncılık.

Todaro, M. P. (1996). Income expectations, rural-urban migration and employment in Afrika. International Labour Review, 135(3-4), 421-444.

Topbaş, F. ve Tanrı̈ver, B. (2009). Türkiye'de iç göç akımları üzerinde bir çalışma: Lowry hipotezi. Dokuz Eylül Üniversitesi İktisadi ve İdari Bilimler Fakültesi Dergisi, 24(1), 93-104.

Türkiye İstatistik Kurumu (TÜİK). (2013). Nüfus projeksiyonları 2013-2075 [basın bülteni]. Erişim adresi: http://www.tuik.gov.tr/ PreHaberBultenleri.do?id=15844

Türkiye İstatistik Kurumu (TÜİK). (2005). Genel nüfus sayımı, 2000 göç istatistikleri. Ankara: Devlet İstatistik Enstitüsü.

Türkiye İstatistik Kurumu (TÜİK). (2016a). Göç istatistikleri. Erişim adresi: http:// www.tuik.gov.tr/VeriBilgi.do?alt_id=1067

Türkiye İstatistik Kurumu (TÜİK). (2016b). Genel nüfus sayımları. Erişim adresi: http://www.tuik.gov.tr/PreTablo.do?alt_id=1047

Türkiye İstatistik Kurumu (TÜİK). (2016c). Adrese dayalı nüfus kayıt sistemi (ADNKS). Erişim adresi: http://www.tuik.gov.tr/PreTablo. do?alt_id $=1059$

Tütengil, C. (1983). 100 soruda kırsal Türkiye'nin yapısı ve sorunlarl. İstanbul: Gerçek Yayınevi.

Tütengil, C. (1985). Sorunlar-öneriler-çözümler. O. Arı (Ed.), Köy sosyolojisi okuma kitabı içinde (s. 137-145). İstanbul: Boğaziçi Üniversitesi Yayınları.

Uysal, M. ve Aktaş, S. (2011). Sıralı regresyon analizi ile Türkiye'deki iç göçleri etkileyen faktörlerin belirlenmesi. Çukurova Üniversitesi Sosyal Bilimler Enstitüsü Dergisi, 20(3), 191-200.

Yalçın, C. (2004). Göç sosyolojisi. Ankara: Anı Yayıncılık.

Yamak, R. ve Yamak, N. (1999). Türkiye'de gelir dağılımı ve iç göç. Dokuz Eylül Üniversitesi Sosyal Bilimler Enstitüsü Dergisi, 1(1), 26-39.

Y1lmaz, A. (2014). "Uluslararası göç: Çeşitleri, nedenleri ve etkileri”, Journal of Turkish Studies, 9(2), 1685-1685. 